\title{
67-kDa laminin receptor and cGMP induced cancer-selective apoptosis
}

\author{
Motofumi Kumazoe ${ }^{1 *}$, Hirofumi Tachibana ${ }^{1,2}$
}

From 6th International Conference on CGMP: Generators, Effectors and Therapeutic Implications

Erfurt, Germany. 28-30 June 2013

\section{Background}

EGCG ((-)-epigallocatechin-3-O-gallate), a polyphenol in green tea, induces apoptotic cell death in cancer cells without affecting normal cells and several clinical trials have been carried out to evaluate its potential value $[1,2]$. 67$\mathrm{kDa}$ laminin receptor $(67 \mathrm{LR})$ has been identified as an
EGCG receptor [3]. It has recently been demonstrated that overexpressed 67LR in multiple myeloma (MM) mediates EGCG-induced cancer-specific apoptosis [4-6]. In this study, we revealed that cGMP acts as a cell death mediator of the EGCG-induced anti-MM effect through acid sphingomyelinase (ASM) activation. In this apoptosis

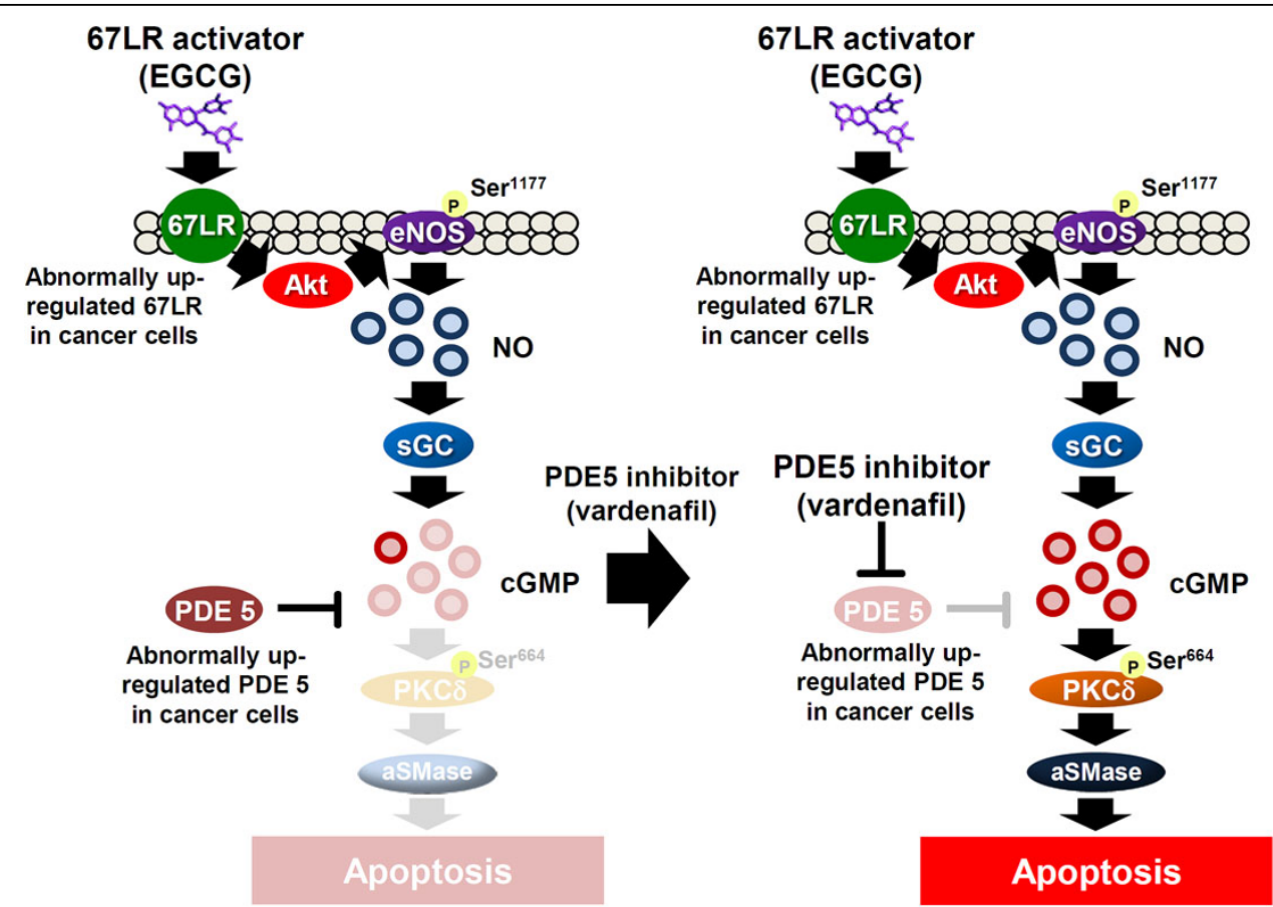

Figure 1 EGCG activates the endothelial nitric oxide synthase (eNOS)/cGMP axis via cancer-overexpressed 67LR (A) EGCG induced eNOS activation through $67 \mathrm{LR}$.

'Division of Applied Biological Chemistry, Department of Bioscience and Biotechnology, Faculty of Agriculture, Kyushu University, Fukuoka 812-8581,

Japan

Full list of author information is available at the end of the article 
pathway, EGCG activated the endothelial nitric oxide synthase (eNOS)/cGMP axis, a well-known mechanism in vascular homeostasis via cancer-overexpressed 67LR. We also demonstrated that cGMP negative regulator, phosphodiesterase 5 (PDE5), was overexpressed in MM cells, and vardenafil, PDE5 inhibitor synergically enhanced the anti-MM effect of EGCG (see Figure 1). This regimen in combination killed MM via overexpressed 67-kDa laminin receptors without affecting normal PBMCs.

\section{Conclusion}

In this study, we demonstrate 67LR activated the peculiar apoptotic signalling eNOS/NO/ cGMP/protein kinase $C \delta$ (PKC $\delta$ ) pathway. Furthermore, we show the upregulation of cGMP is rate-determining process of this cell death pathway. We demonstrate cancer overexpressed negative regulator of cGMP, PDE5 attenuates the cGMP-dependent cell death induced by EGCG. Vardenafil, one of the PDE5 selective inhibitors used for treating erectile dysfunction potentiates anti-cancer effect of EGCG. These results demonstrate that cGMP elevation caused by targeting the overexpressed 67LR and PDE5 in cancer cells may be a useful approach for cancer-specific chemotherapy.

\section{Authors' details}

'Division of Applied Biological Chemistry, Department of Bioscience and Biotechnology, Faculty of Agriculture, Kyushu University, Fukuoka 812-8581, Japan. ${ }^{2}$ Food Functional Design Research Center, Kyushu University 8128581, Japan.

Published: 29 August 2013

\section{References}

1. Shanafelt TD, Call TG, Zent CS, Leis LF, Plant BL, Bowen DA, Roos M, Laumann K, Ghosh AK, Lesnick C, Lee MJ, Yang CS, Jelinek DF, Erlichman C, Kay NE: Phase 2 trial of daily, oral Polyphenon E in patients with asymptomatic, Rai stage 0 to II chronic lymphocytic leukemia. Cancer 2013, 119:363-370.

2. Bettuzzi S, Brausi M, Rizzi F, Castagnetti G, Peracchia G, Corti A: Chemoprevention of human prostate cancer by oral administrationof green tea catechins in volunteers with high-grade prostate intraepithelial neoplasia: a preliminary report from a one-year Proof-of-Principle study. Cancer Res 2006, 66:1234-1244.

3. Tachibana H, Koga K, Fujimura Y, Yamada K: A receptor for green tea polyphenol EGCG. Nat Struct Mol Biol 2004, 11:380-381.

4. Shammas MA, Neri P, Koley H, Batchu PB, Bertheau RC, Munshi V, Prabhala R, Fulciniti M, Tai Y, Steven P, Treon SP, Goyal RK, Anderson CK, Munshi NC: Specific killing of multiple myeloma cells by (-)-epigallocatechin-3-gallate extracted from green tea: biologic activity and therapeutic implications. Blood 2006, 108:2804-2810.

5. Tsukamoto S, Hirotsu K, Kumazoe M, Goto Y, Sugihara K, Suda T, Tsurudome Y, Suzuki T, Yamashita S, Kim Y, Huang Y, Yamada K, Tachibana H: Green tea polyphenol EGCG induces lipid-raft clustering and apoptotic cell death by activating protein kinase Cdelta and acid sphingomyelinase through a $67 \mathrm{kDa}$ laminin receptor in multiple myeloma cells. Biochem J 2012, 443:525-534.

6. Kumazoe M, Sugihara K, Tsukamoto S, Huang Y, Tsurudome Y, Suzuki T, Suemasu Y, Ueda N, Yamashita S, Kim Y, Yamada K, Tachibana H: 67-kDa laminin receptor increases CGMP to induce cancer-selective apoptosis. J Clin Invest 2013, 123:787-799.
doi:10.1186/2050-6511-14-S1-033

Cite this article as: Kumazoe and Tachibana: 67-kDa laminin receptor and cGMP induced cancer-selective apoptosis. BMC Pharmacology and Toxicology 2013 14(Suppl 1):O33.

\section{Submit your next manuscript to BioMed Central and take full advantage of:}

- Convenient online submission

- Thorough peer review

- No space constraints or color figure charges

- Immediate publication on acceptance

- Inclusion in PubMed, CAS, Scopus and Google Scholar

- Research which is freely available for redistribution

Submit your manuscript at www.biomedcentral.com/submit
C Biomed Central 